
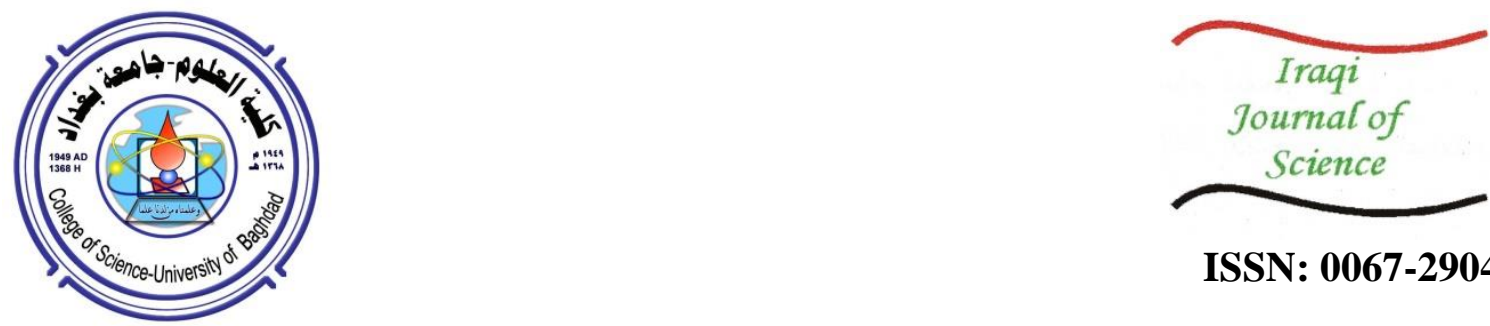

ISSN: 0067-2904

\title{
2D Seismic Reflection Study of the Cretaceous-Tertiary Period in Qasab- Jawan Area in Northwestern Iraq
}

\author{
Marwa H. Shehab*' Kamal K. Ali \\ Department of Geology, College of Science, University of Baghdad, Baghdad, Iraq.
}

Received: $13 / 12 / 2020 \quad$ Accepted: 21/3/2021

\begin{abstract}
A seismic study was conducted to re-interpret the Qasab and Jawan oil field in northern Iraq, south of the city of Mosul, by reprocessing and interpreting many seismic sections of a number of field surveys that included the field area. Two reflectors are detected, represented by Hartha Formations which were deposited during the Cretaceous age and Euphrates Formation which was deposited during the Tertiary age in order to stabilize the structural image of this field. The study was achieved by reinterpreting seismic sections using the Petrel program, where time, velocity and depth maps were prepared for the two formations.

The study showed that the Qasab and Jawan fields generally consist of a structural closure located at the wells of the northern dome. This closure extends to the south east and deviates towards the east in the form of a structural rift. The study concluded the existence of a transverse fault that cuts Qasab and Jawan structures, forming a structural trap that represents the southern part of Qasab structure.
\end{abstract}

Keywords: Structural interpretation,seismic reflection,Qasab-jawan area

دراسه زلزاليه انعكاسيه ثنائيه الابعاد للفتره الطباشيري-الثلاثي في منطقه قصب-جوان شمال غرب

$$
\begin{aligned}
& \text { مروه حمزه شهاب *، كمال كريم علي }
\end{aligned}
$$

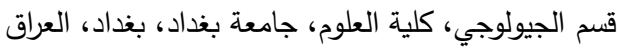

$$
\begin{aligned}
& \text { الخلاصة } \\
& \text { تم اجراء دراسة زلزالية لإعادة تفاسير حقل قصب وجاوان النفطي الواقع شمال العراق جنوب مدينة }
\end{aligned}
$$

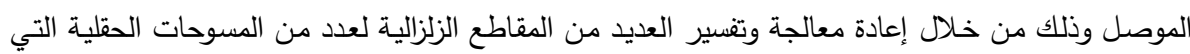

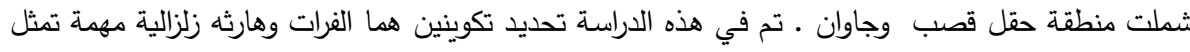

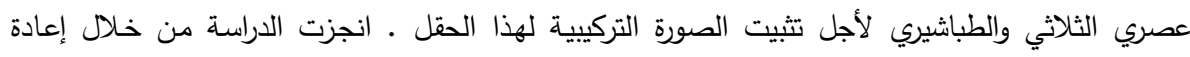

$$
\begin{aligned}
& \text { تفاسير المقاطع الززالية باستخدام برنامج بترل حيث تم اعداد خرئط زمنية وسرعية وعمقية شملت تركيب }
\end{aligned}
$$

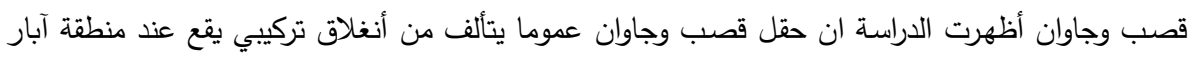

$$
\begin{aligned}
& \text { القبة الثمالية يمتد هذا ألأنغلاق بالأتجاه الجنوبي الثرقي ومنحرفا بأنجاه الثرق على الثلى شكل خثم تركيبي }
\end{aligned}
$$

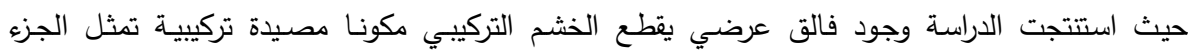

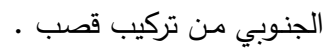

*Email: ams.marwamaram@yahoo.com 


\section{Introduction}

The study of geophysical history of accumulations of hydrocarbons returns to the beginning of the last century and seismic analyses of the reflexes were used to detect these accumulations [1]. In terms of costs and the number of geophysicists involved, the seismic approach is the most effective geophysical technique. The predominance of the seismic process over geophysical methods is due to numerous factors, including high precision, high resolution and high permeability,. The seismic methods are the most used in the petroleum discovery of all geophysics [2] .

The task of seismic analysis in oil studies is to provide a most accurate picture of the surface of the earth and its geological structures in order to determine the seismic portion, velocity and time outline, as well as seismic stratigraphy and seismic facies in terms of intra-stratigraphic interpretations [3]. Many seismic studies were conducted to investigate the subsurface geology of many oilfields in Iraq. Those studied concluded that the seismic reflection method provides a good image of the stratigraphy and structure of the subsurface, which leads to understanding the subsurface geology and provide a good evidence of oil accumulation [4-9]. The Qasab and Jawan area, located in south Mosul, northwestern Iraq, was studied by taking data from the Oil Exploration Company (OEC). This research aims to studying the structural pictures in the area, which are covered by 2D seismic survey, and determine the geometric boundaries for its structures. The method of work was created first by the synthesis of a seismogram for the wells of Qasab-11 and Qasab-12. The reflectors of two formations were determined, which are the Euphrates, deposited during the Tertiary period, and Hartha, deposited during the Cretaceous period. Then, time, velocity and depth maps were created for the study area to be iterpreteted..

\section{Location of study area}

The study area represents a vast region of the northwestern part of Iraq. It is located to the south of Mosul city (Figure-1). The UTM coordinates of the study area are listed in Table- 1.

The area is bounded by Sinjar Mountain (anticline), Tela'far, Mosul city from the north, Sunaisla Lake and Hatra from the south, Tigris River from the east, and the Syrian borders from the west. The total area of south Sinjar plain which includes the study area is approximately

[19714 Km ]. The area is covered by Quaternary deposits of Pleistocene and Holocene periods, while Tertiary and Cretaceous deposits are not exposed at surface, only far toward the north outside the study area [10]. The Sinjar anticline area is located within the Low Folded Zone, according to the tectonic map of Iraq. It contains outcropping Neogene sedimentary rocks. The cores of the anticlines may expose Eocene limestones or Upper Cretaceous sedimentary rocks [11]. 


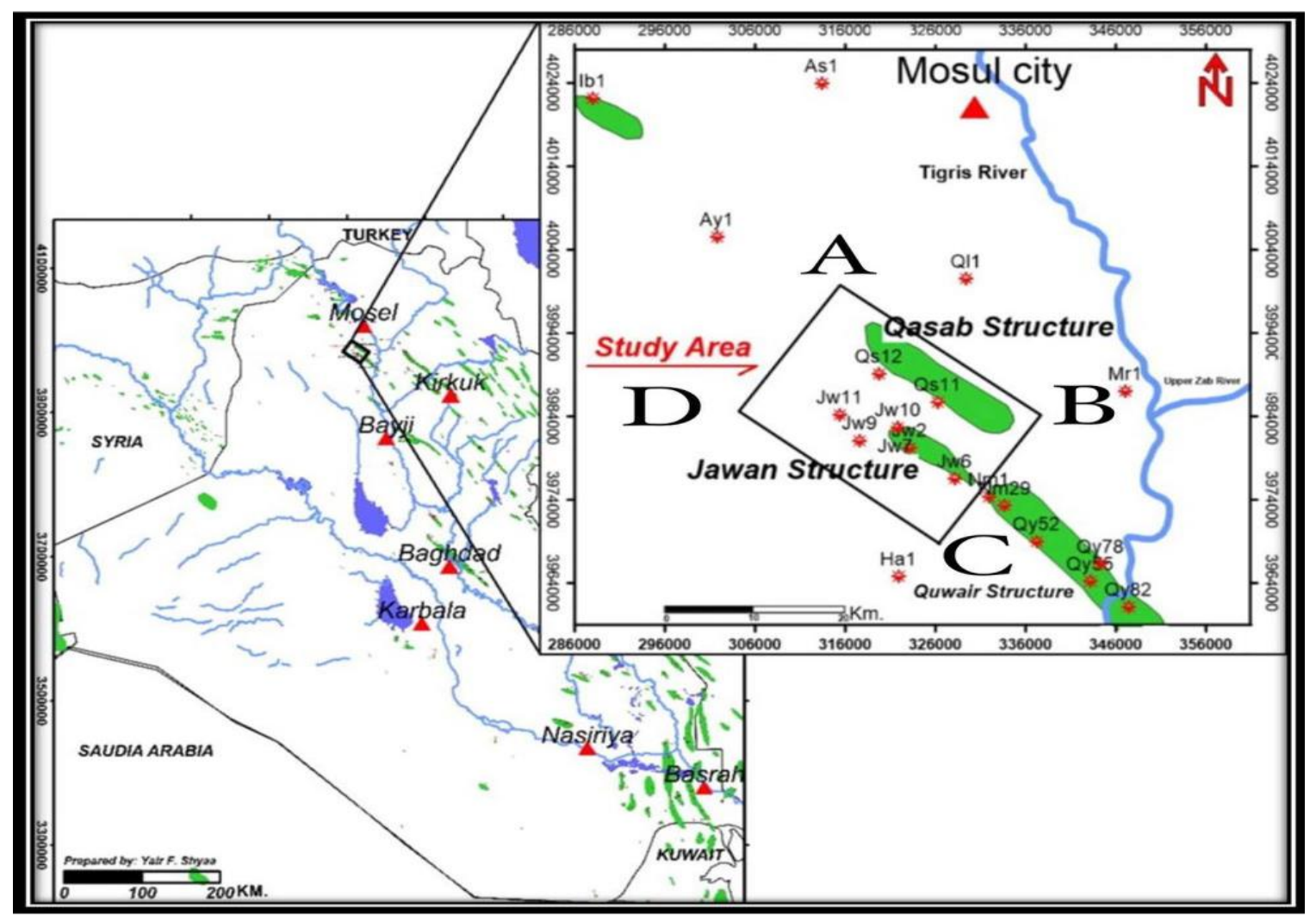

Figure 1- Location map of the study area

Table 1- Coordinates of the study area

\begin{tabular}{|c|c|c|}
\hline Point & Northern & Southern \\
\hline A & 304419.9 & 3984972 \\
\hline B & 315566.3 & 4000040 \\
\hline C & 337579.1 & 3984132 \\
\hline D & 326488.7 & 3968841 \\
\hline
\end{tabular}

\section{Data and Methodology}

The data which are available in the OEC were loaded to the Petrel E\&P software, version 2017. These data include well data (well tops, total depths, records of sonic logs, estimated density and coordinates) and well seismic velocity, including the VSP and the check-shot of wells Qasab-11 and Qasab-12. The data also included seismic data of sets of 2D seismic lines that cover almost all of the study area, carried out by the OEC in 2008. These surveys are the IQ survey, which consists of seven lines : (IQ37, IQ39, IQ41, IQ43, IQ58, IQ62, IQ68) and the QJ survey, which consists of seven lines (QJ9, QJ11c, QJ60, QJ62, QJ64, QJ66, and QJ54).

A base map of seismic lines in the study area was prepared.

1. A synthetic seismogram for the study area was synthesized.

2. Synthetic seismogram were compared with seismic sections near the well to identify the reflectors of the formations in the study area

3. TWT, velocity maps, and depth maps of the target reflectors in the study area were created.

4. The above maps were interpreted in order to obtain the structure image of the study area.

Processed seismic data (in SEG-Y format) were uploaded to the interactive workstation of the Interpretations Department at the OEC with their coordinates. Then, the base map of the study area was constructed. Figure-2 shows the two sets of 2D seismic lines. 


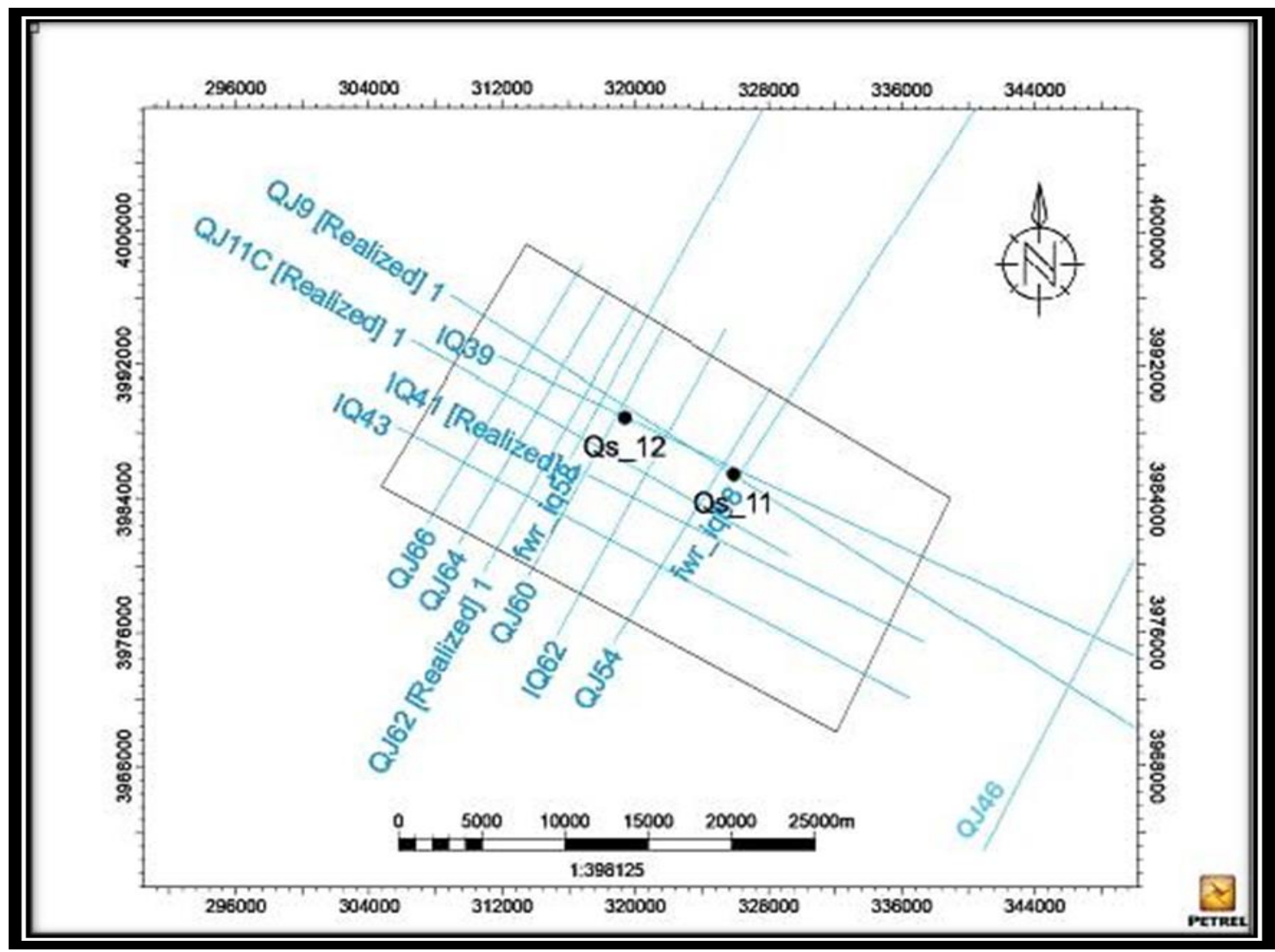

Figure 2- The base map of the study

\section{Generating synthetic seismograms}

The seismic section interpretation method needs to identify reflectors representing studied formations, by comparisons of the periods of time (TWT) reflecion for the seismic section with the synthetic seismogrsms obtained through the sonic log and velocity survey for the well [12].

the main steps for the generation of the synthetic seismogram are :

1- Acoustic impedance calculation $(Z=\rho \times v)$ where :

$\mathrm{v}$ : velocity measured from velocities survey in wells or from sonic log.

$\rho$ : density measured from information of core analysis or from density log.

2- Computing the reflection coefficients, as follows:

\section{$\boldsymbol{R}_{\boldsymbol{i}}=\frac{\left(\rho_{i+1}\right)\left(v_{i+1}\right)-\rho_{i} v_{i}}{\left(\rho_{i+1}\right)\left(v_{i+1}\right)+\rho_{i} v_{i}}$}

where $(\rho \mathrm{i}+1, \rho \mathrm{i})$ are the density values at the interval $(\mathrm{i}),(\mathrm{i}+1)$

and (vi+1, vi) are the velocity values at the interval (i), $(i+1)$

The reflection coefficients in the depth domian were converted to reflectivity function in the time domain [13]. Then, the experimental wavelet was extracted from the seismic data nearest to the well, using Petrel software.

3- Finally, synthatic seismograms were generated for two wells (Qs-11, Qs-12) using Petral software package ( Figures- 2 and 3 ) by the convolution of the reflectivity functions and the extracted wavelet. Generally, the accuracy and quality of the synthetic seismogram depends on the ability of extracting a suitable wavelet, quality of sonic log, and quality of seismic data [13-15].

The comparison of the seismic data with the synthetic seismogram shows acceptable- poor matching between the seismic reflectors. It also shows that the upper contact of Euphrates and Hartha formations is in the peak of the amplitude of the wavelet. Due to that, the reflection coeffeicents are positive. 


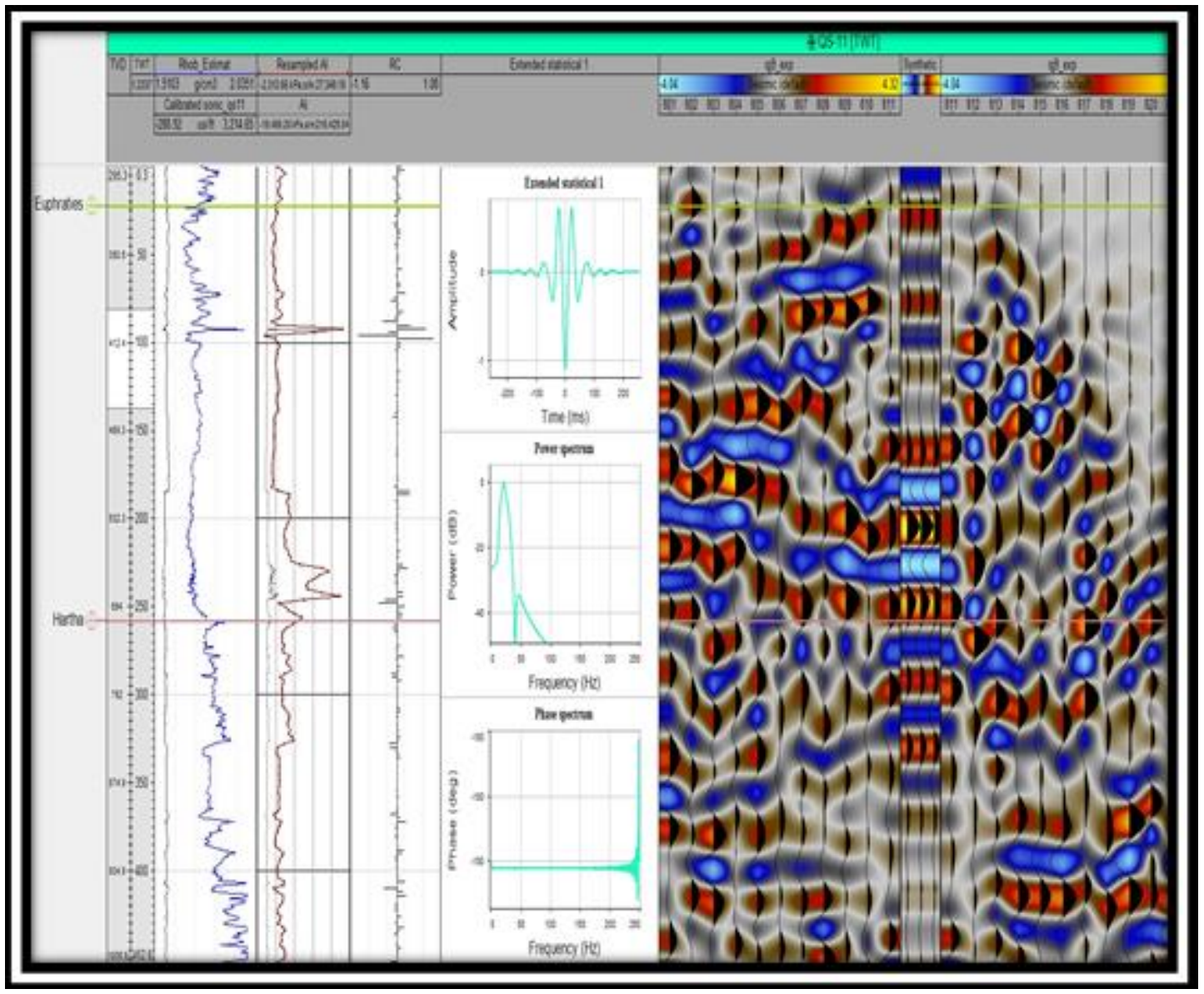

Figure 3- The synthetic seismogram of the Qs-11 well 


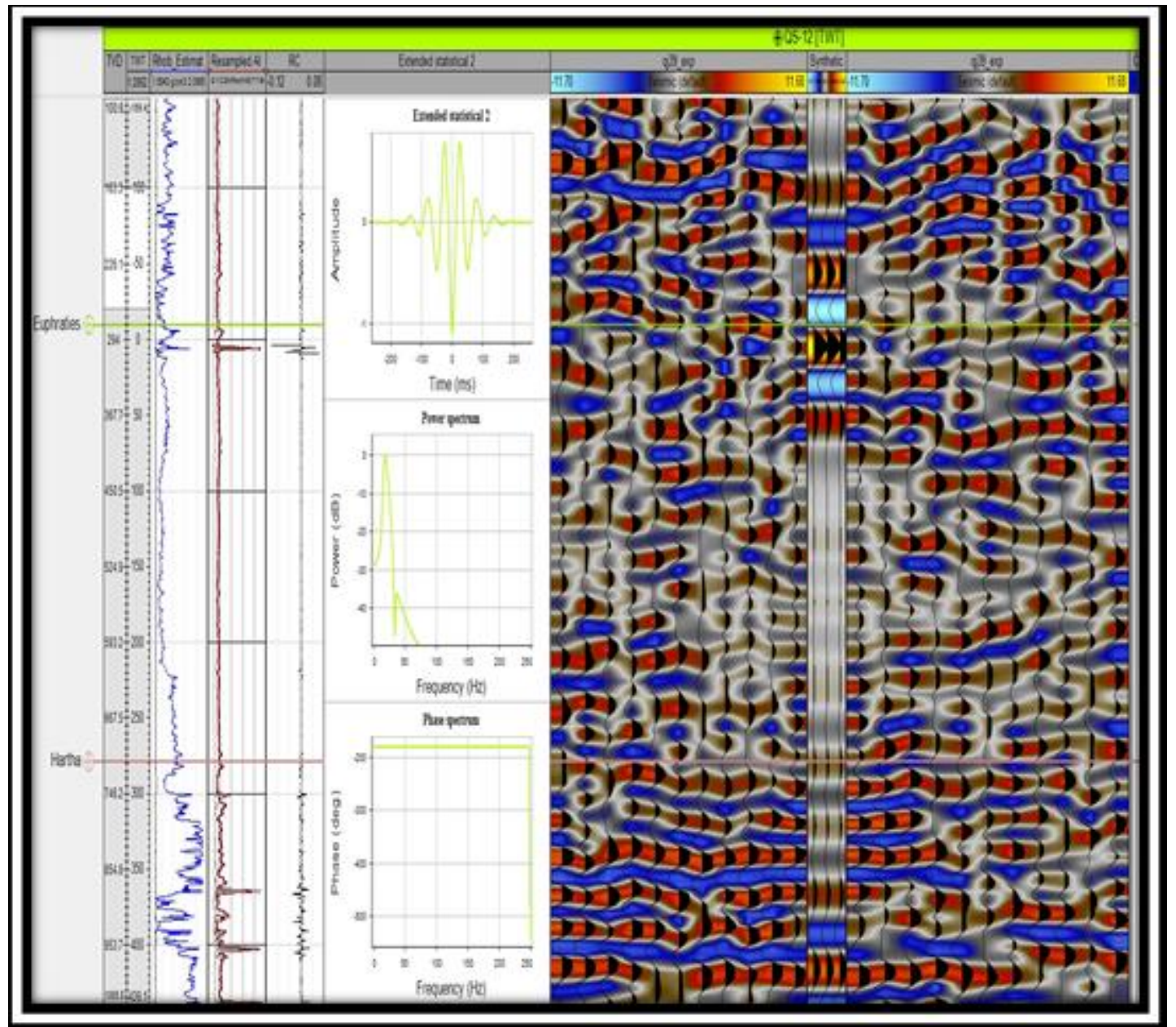

Figure 4- The synthetic seismogram of the Qs-12 well .

\section{Seismic Data Interpretation}

Seismic interpretation is an important and last phase of any seismic exploration project. This involves the transfer of the processed seismic data into similar geological information $[15,16]$.

The interpretation process was performed in several steps.

The reflectors of Euphrates and Hartha were identified and picked on all seismic lines that cover the study area.

The structural features in the region were determined.

Structural mapping in the time and depth domains was performed. Reflection events were recorded in two-way time (TWT). Average velocity values of Qs-11 and Qs-12 wells were used to convert maps from time domain into depths domain.

\section{Results and discussion}

\section{Time maps}

Two-way time maps for the two reflectors (Top euphrates and Top Hartha) were prepared. The time maps may contain essential geological details on the subsurface [15].

These reflectors represent potetial oil reservors within their deposition periods. The Euphrates represents one of the impotant formations of the Miocene era formations within the tertiary period in the Qasab field. The Hartha reflector is considered as the most important reservoir in the Qasab sturucture. It is one of the formations of the upper Cretaceous Era.

\section{Top Euphrates time map}

This map shows a closure structure which represents the Jawan structure. The wells of the Jawan oilfield are distributed around this closure. This closure is confined between the QJ-64 and the QJ-46 seismic lines. A shallow depression that is separating the Qasab and Jawan oil fields could be noticed in this map (Figure- 5) 


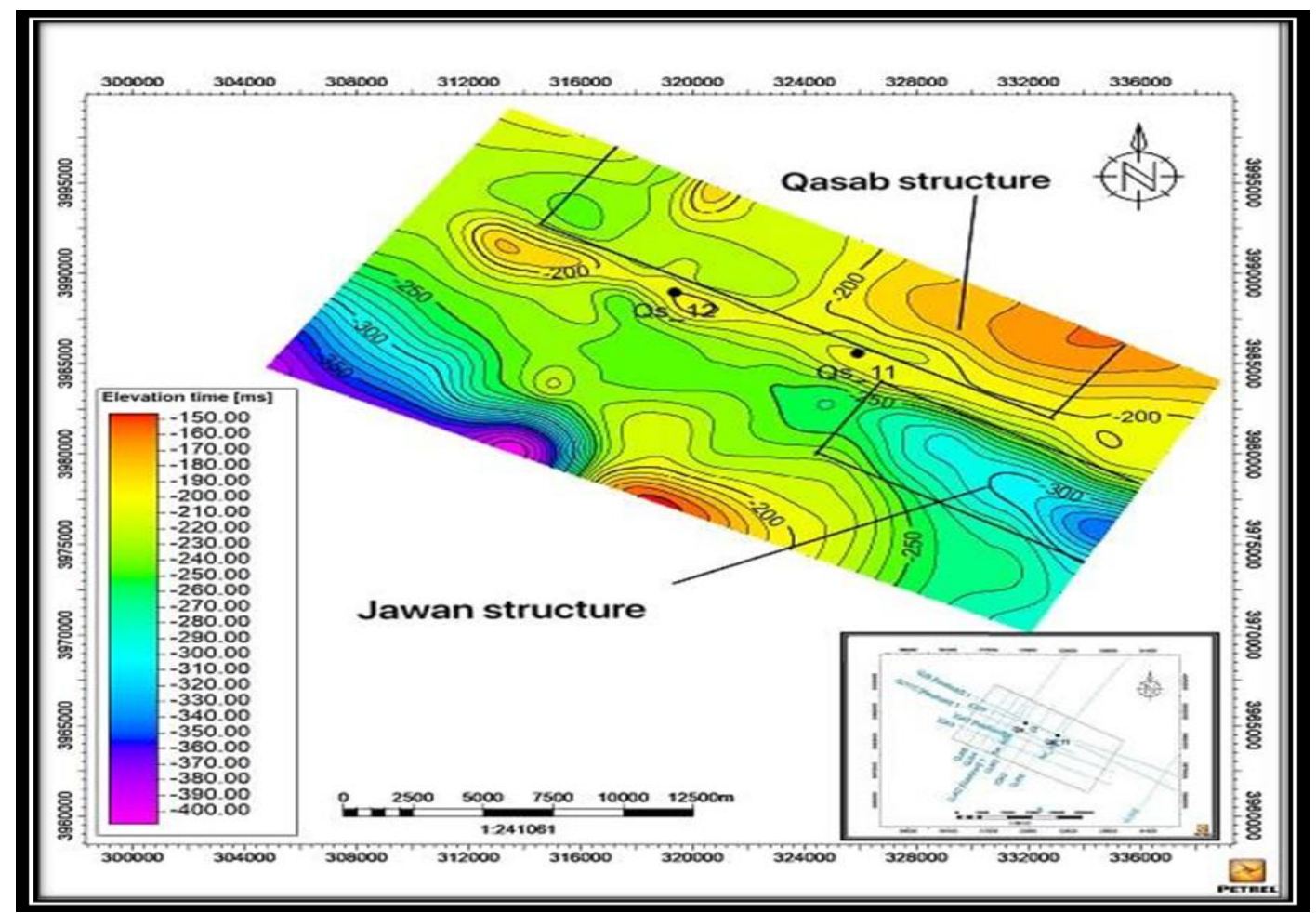

Figure 5- Top Euphrates time map.

\section{Top Hartha time map}

The location of the closure which is defined in the Top Euphrates time map of the Jawan oilfield is confined between the QJ-64 and the QJ-46 seismic lines in this map. The map also shows a closure structure to the south of the wells of the Jawan field. The map shows the presence of a shallow time depression separating the Qasab and Jawan oil fields. As for the Qasab oil field, which consists of an enclosure located in the wells of the northern dome, there is a component of a time structure deviates slightly towards the east in the wells of the southern dome (Figure- 6).

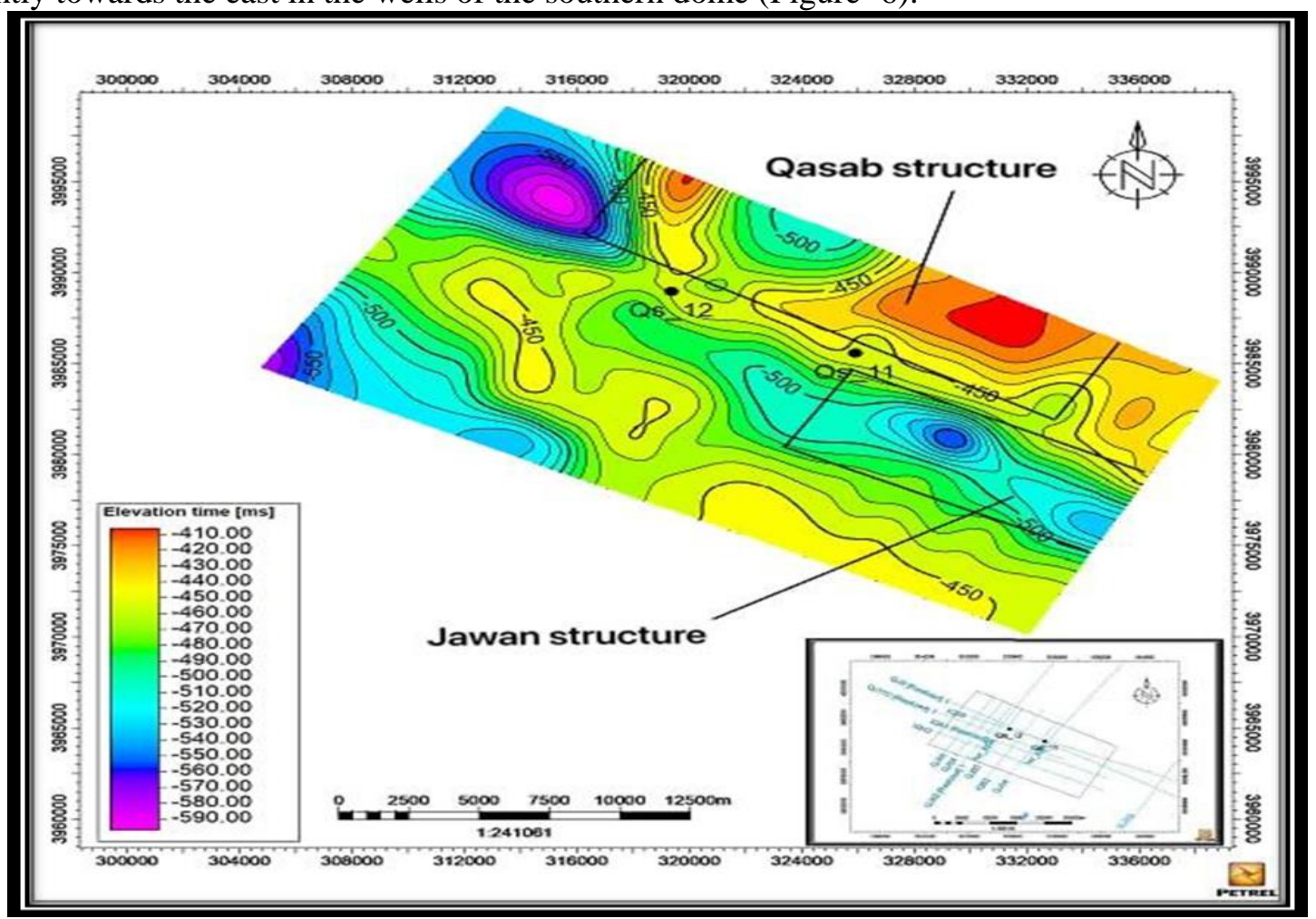

Figure 6-Top Hartha time map. 


\section{Velocity map}

The average velocity is the required velocity for converting TWT maps into depth maps. It is considerd as a more precise velocity campared with that used in seismic methods and can be determined directly from a well velocity survey (check shot) [17].

The average velocity map showed that the velocity increases in general irregularly with increasing depth, because of the heterogeneity of sedimentary layers as a result of differing in facies and depositional environment.

Average velocity assessment is an accurate, but typically a tough, task that is required for reliable results of reservoir faces, depths, thicknesses, porosities and fluid material. Several methods are available for 2D seismic velocity evaluation and the correct option depends on the type of data and the skill and experience of the interpreter [18].

\section{Euphrates velocity map}

The velocity map of this reflector (Figure- 7) shows increasing velocity in the west and northwest direction, ranging from 2810 to $3130 \mathrm{~m} / \mathrm{s}$, and a decreasing velocity in the east direction.

This is explained by the gradually fading of the sedimentary basin towards the east, due to approaching the coast, and thus the decrease in the weight of the sedimentary column, which has effects of a relatively decrease in velocity. While the increase of velocity in the western and northwestern directions is caused by an increase in the weight of the sedimentary column towards the bottom area of the sedimentary basin.

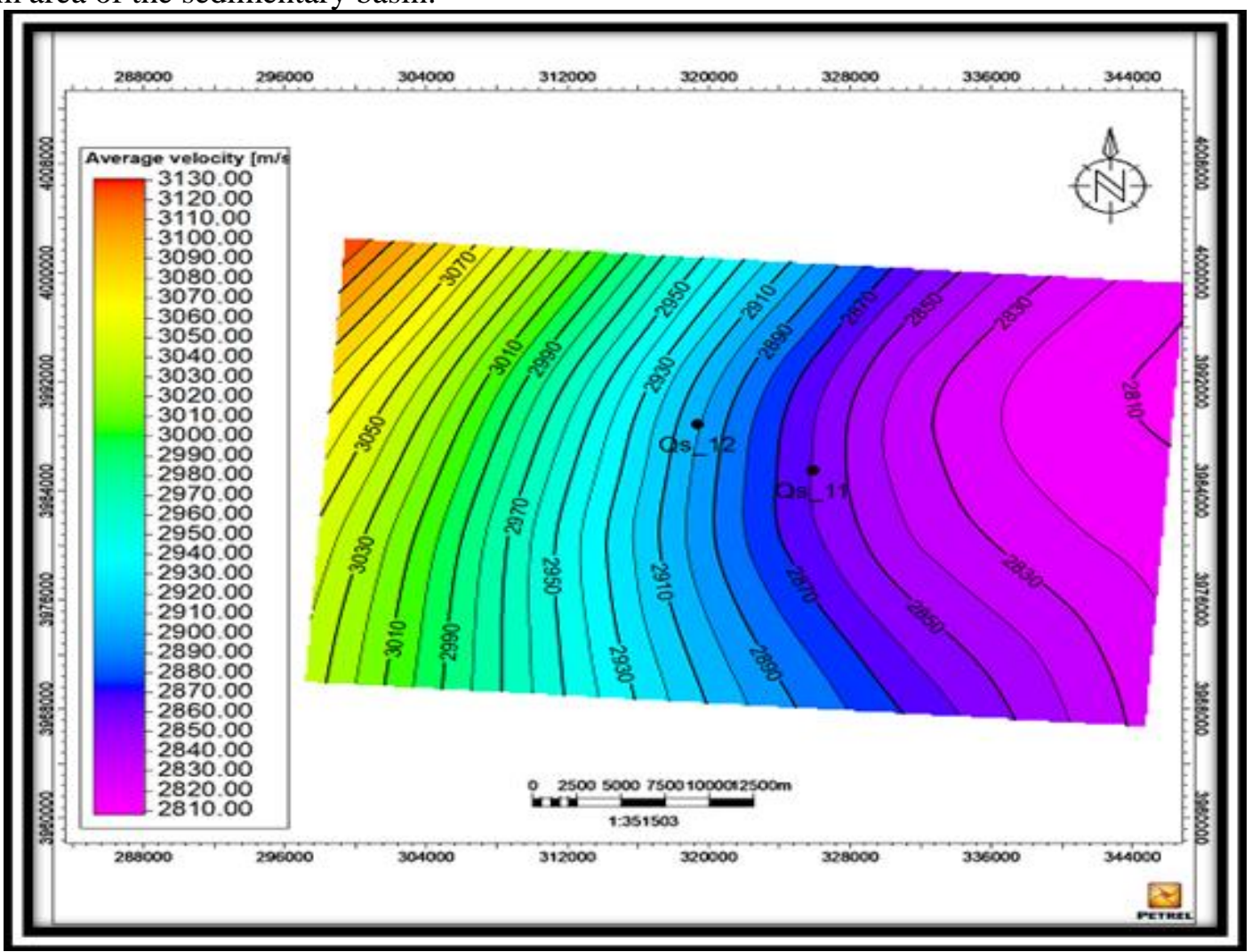

Figure 7- Euphrates average velocity map

\section{Hartha velocity map}

The velocity map of this reflector (Figure- 8) shows an increasing velocity in the directions of the west and northwest, ranging from 3090 to $3270 \mathrm{~m} / \mathrm{s}$ and a decreasing velocity in the direction of the east. of the increase in velocity in these directions is due to increasing the sedimentary column of the basin. 


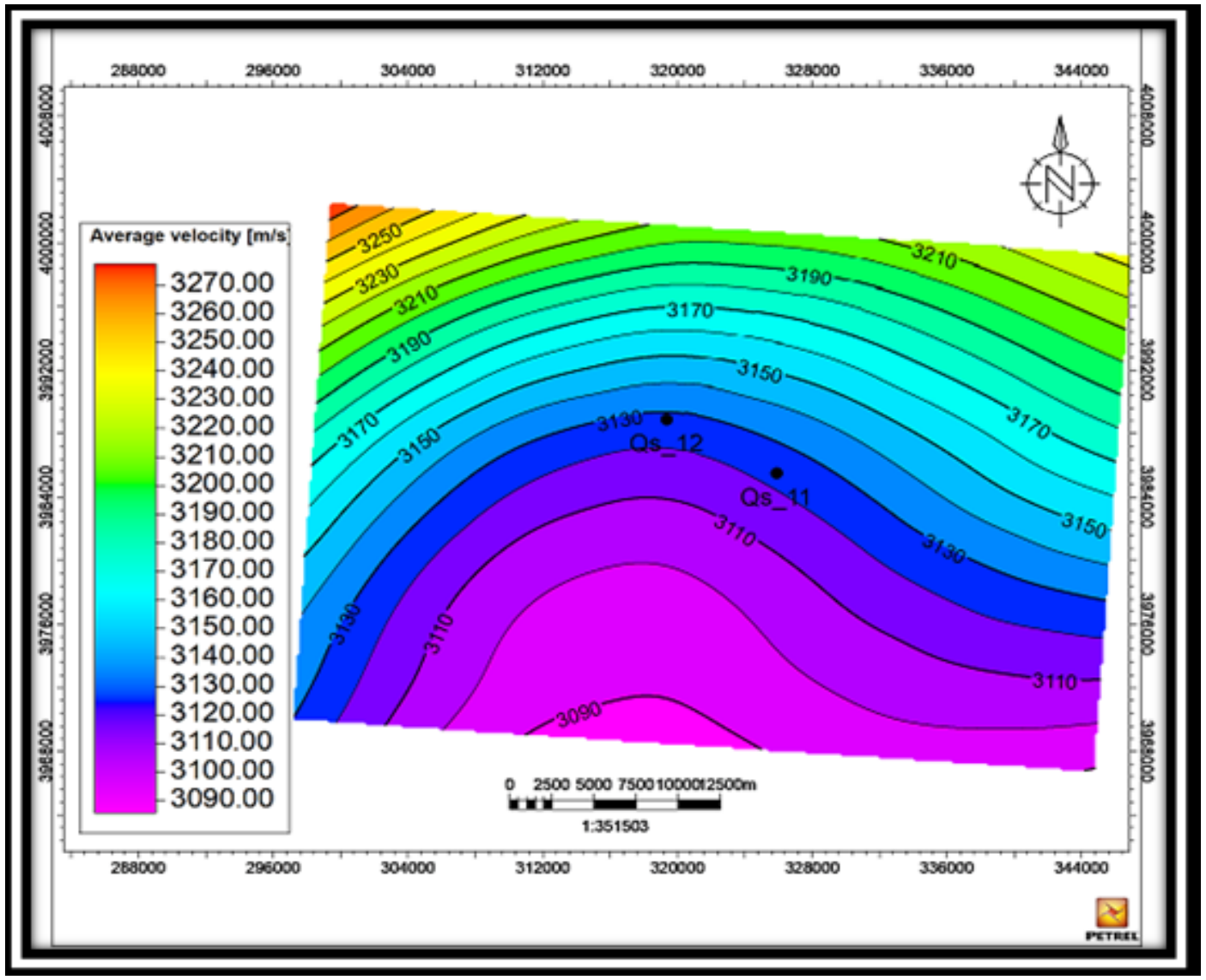

Figure 8- Hartha average velocity map

\section{Depth maps}

The depth map is an important step in the seismic reflection method, which permits the production of depth and thickness of depict subsurface layers based on reflection data. The extract of the depth map values from the time map of a given reflector with its average velocity map will be given as follows: Depth at any point $=($ Average velocity $\times$ TWT /2) at this point. The shape of depth maps might look like that of a two-way time map, which shows the same picture of the studied formation, but the difference lies in the closures dimensions and locations, faults displacements, and difference in the number of minor faults [19].

\section{Top Euphrates depth map}

The depth map of this formation (Figure- 9) shows the presence of a structural closure that extends in the northwest-southeast direction. This structural closure is confined between the QJ-64 and the QJ46 seismic lines (Figure-1). This closure extends in the southeast direction and deviates towards the east. Also, the map shows the presence of a shallow time depression separating the Qasab and Jawan oil fields. 


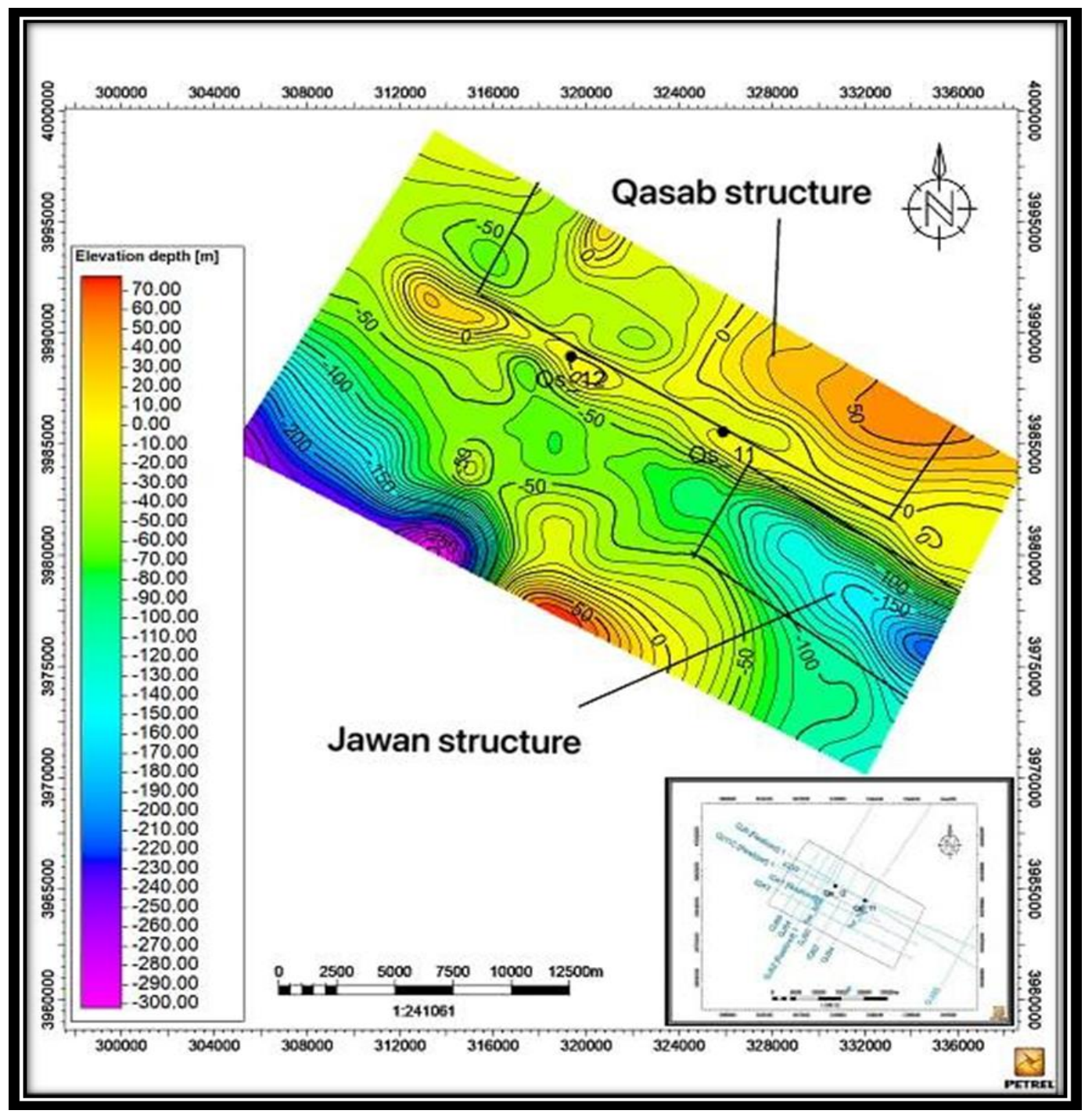

Figure 9- Top Euphrates depth map

\section{Top Hartha depth map}

The depth map of Hartha Formation (Figure-10) shows the presence of a structural closure extending in a northwest-southeast direction. This structural closure is limited between the QJ-64 and the QJ-46 seismic lines (Figure-1). This closure extends to the southeast and diverges towards the east. 


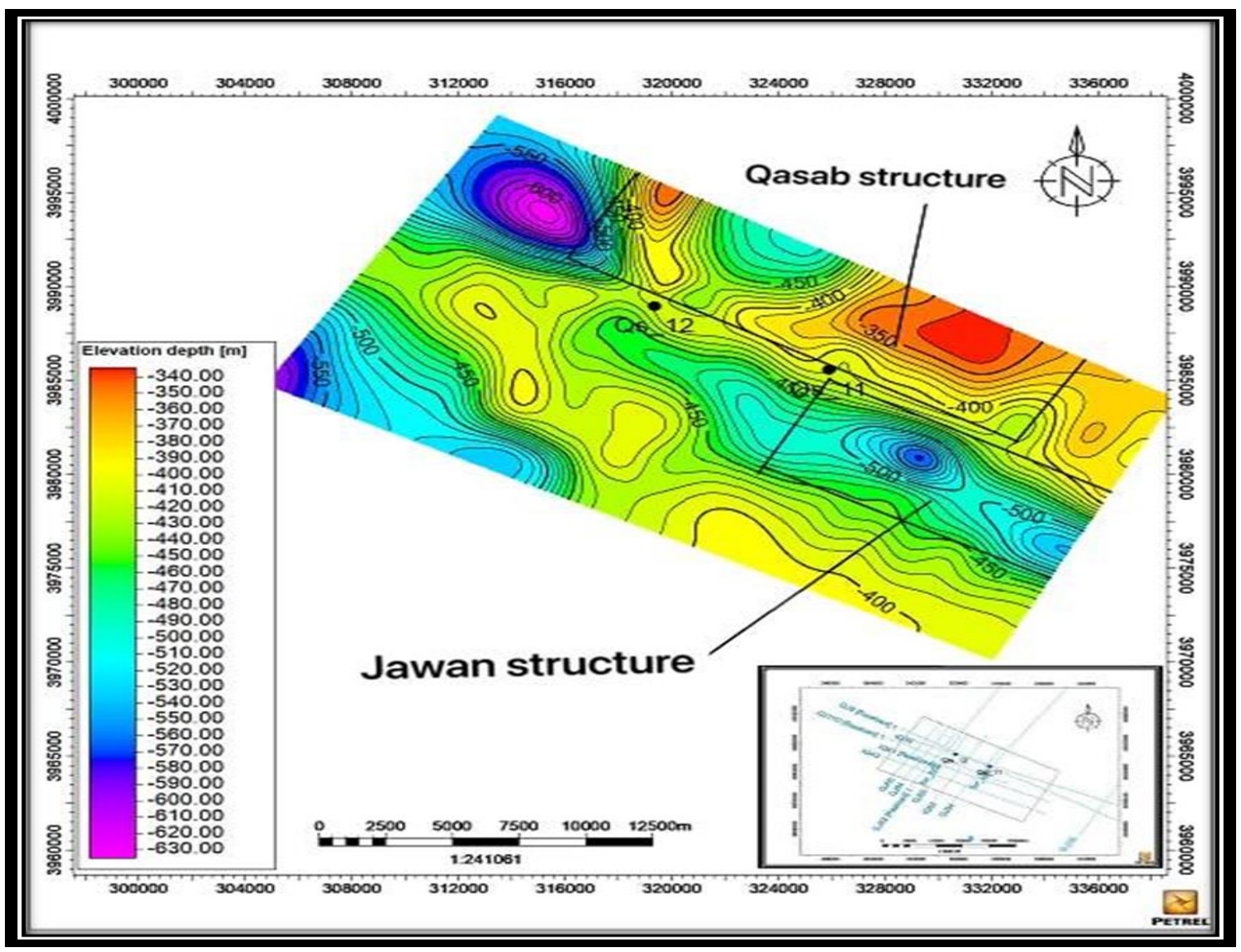

Figure10- Top Hartha depth map

\section{Conclusions}

The present study has reached a number of conclusions.

1- The decline of the reflectors within all formations covered by the study is trending towards the southeast.

2- The Qasab structure within the formation of the current study consists of a structural closure in the area of the wells of the northern dome. This extends the locking component of the structure. It extends in a south eastern direction and tapers towards the east at the wells of the southern dome of the field.

3- The Qasab and the Jawan oilfields are two separated fields, in the middle of which is a shallow structural center. Therefore, it is expected that there will be a longitudinal fault separating the Qasab field and the Jawan field and extending parallel to them.

4- It is expected that there will be a transverse fault separating the closing of the northern dome from the south dome of the Qasab field. This difference may be the cause of the presence of oil in this part of the composition of the reservoir formations in the Qasab oil field.

\section{References}

1. Dobrin, M. 1976. Introduction to Geophysical Prospecting, 3rd ed., McGraw Hill. Int. co., International Student Edition $386 \mathrm{p}$

2. Hart, Bruce S. 2004. Principle of $2 D$ and $3 D$ seismic interpretation, McGill University

3. Milsom, John. 2003. Field Geophysics, 3rd. Ed. University College London

4. Ali K.K. And Kadhim G.F. 2020. 3d Seismic Attributes Interpretation Of Zubair Formation In AlAkhaideir Area, Southwestern Karbala. Iraqi Geological Journal, 53(1d), 2020.

5. Ali K.K. And Kadhim G.F. 2020. 3D Seismic Reflection Study of Al-Akhadeir Area, Southwestern Iraq. Iraqi Journal of Science, 61(11): 3035-3046 
6. Obaid F.A. and Al-Rahim A.M. 2019. Pre and Post-Stack Imaging of 2D Seismic Data Using Time Migration for Ajeel Oil field, Central of Iraq. Iraqi Journal of Science, 60(10): 2186-2195

7. Hashim, H.A. 2017. Seismic inversion as a tool for reservoir characterization at Zubair and Mishrif Formations in Al-Rafidain oil field- southern Iraq. PhD Thesis, University of Baghdad, 144p. (Unpublished).

8. Khalil A.I. 2018. Structural, stratigraphic and processing study of Nahr Umr Formation using 3D seismic survey in Abo Amood oil field, south of Iraq. MSc. Thesis, university of Baghdad, 97p. (Unpublished).

9. Khorshid S.Z., Alki, H.D. and Ziad, M. A. 2016. Subsurface investigation of Marjan oil field depending oi 3D seismic reflection, central Iraq. Iraqi Journal of science, 157(4A): 2457-2469

10. Daoud Y.N., 1986,"application of electrical resistivity method for hydrogeological investigations in south Sinjar area", MSc. Thesis, university of Baghdad / College of Science/Dept. of Geology.157pages

11. Jassim, Saad Z. and Goff, Jeremy C. 2006. Geology of Iraq, Czech Republic, ISBN 80-7028-287-8

12. Lindseth, R. 0. 1979. Synthetic sonic logs-a process for stratigraphic interpretation .

13. Sheriff, R.E., and Geldart, L.P. 1995. Exploration seismology. Cambridge University press.380p

14. Brown, A.R. 2011. Interpretation of Three-Dimensional Seismic Data: AAPG Memoir 42, /SEG Investigation in Geophysics, 42(9). AAPG

15. Alsadi, H.N. 2017. Seismic Hydrocarbon Exploration $2 D$ and $3 D$ Techniques. Springer international publishing, Switzerland. 331p. DOI 10.1007/978-3-319-40436-3

16. Alridha, N.A. and Al-khafaji, H. J. 2019. Stratigraphic and Structural Study of Khlesia Region Using 2D Seismic Data - North Western Iraq, Iraqi Journal of sciences, 60(2): 277-289

17. McQuillin R., Bacon M., and Barclay W. 1984. An Introduction to Seismic Interpretation, Graham and Trotman, $287 \mathrm{p}$.

18. Nanda N. C. 2016. Seismic Data Interpretation and Evaluation for Hydrocarbon Exploration and Production, Cuttack, Odisha, India, 224 p. 